\title{
Error Analysis at Segmental Phonology in Pondok Pesantren Modren Nurul Hakim, Medan
}

\author{
Lahmuddin Lubis ${ }^{1}$, Dairina Yusri ${ }^{2}$, Zuhria $^{3}$ \\ ${ }^{1}$ Arabic Department, Tarbiyah and Education Faculty, State Islamic University, UINSU, Indonesia \\ ${ }^{2}$ Islamic Religion Department, STAIS Sumatra, Medan, Indonesia \\ ${ }^{3}$ Islamic Religion Department, Tarbiyah and Education Faculty, State Islamic University, UINSU, Indonesia
}

\begin{abstract}
Language is the ability to acquire and use complex systems of communication, particularly the human ability to do so, and a language is any specific example of such a system. The scientific study of language is called linguistics. Error analysts distinguish between errors, which are systematic, and mistakes, which are not. They often seek to develop a typology of errors. Error can be classified according to basic type: omissive, additive, substitutive or related to word order. They can be classified by how apparent they are: overt errors such as "I angry" are obvious even out of context, whereas covert errors are evident only in context. Closely related to this is the classification according to domain, the breadth of context which the analyst must examine, and extent, the breadth of the utterance which must be changed in order to fix the error. Errors may also be classified according to the level of language: phonological errors, vocabulary or lexical errors, syntactic errors, and so on. the most error done by respondents in spoken Arabic is the form error replacement (substitution) accounted for 17 errors with percentage as much as $77.27 \%$, the error being the addition totaling 3 percentage error by as much as $13.64 \%$ and fewest errors is omission (omission) amounted to 2 fault with the percentage as much as $9.09 \%$.
\end{abstract}

Keywords: Error analysis; phonology; segmental; language; intralingual; interlingual

\section{INTRODUCTION}

Language is a mean of communication among humans used to describe thoughts, feelings and intentions of his heart. Language is also used to distinguish humans and animals because language is a special ability possessed only by human being. Human being is always bound by the language they use because every society is formed, live and grow up with the language. Every human has a language because without language human being cannot hang out with each other on all the activities carried out on social, economic, political, etc. Language is so close to human beings and the language is so united in human life, so the human understanding of the nature of language adds to growing evidence of human closeness and unification with the language. By the reason of fulfilling needed, human not only master their mother tongue, but also have a desire to master other languages. In other to master it, it needs learning process. According to Suwama Pringgawidagda, there are two types of learners' language in mastering the target language. Both types are languages to be mastered formally and informally. This formal studying is performed in the classroom and a learning environment that focuses on mastery of realizing the rule or rules language target.In the process of learning activities, learners try to master target language (foreign language) as well as native speakers. A learner who is successfully to master the skills of target language, he has the same ability with the owner of the language. But in reality, it does not always happen. The language learners are often characterized by deviation that includes in all levels of language. The level of grammatical problem of the language are morphology, syntax, semantics, phonology, lexicon and discourse. These deviations occur when learners want to learn any languages. It also happens the same when the leaner would like to Arabic language as a target language. The term deviation is then known as the linguistic error.

\section{METHODOLOGY}

\subsection{Error Analysis}

In our daily activities, we often hear the term analysis, especially in the world of education. The term is often used in research activities to analyze the data or information that has been collected. This analysis is one of the steps in doing a research. In doing a research, analyzing is separating the data and classify it in accordance with the details of their problems then compared with one another. Thus we can understand that analyzing is separated one apart to another. For example, when we see an elephant, then in our mind we try to separate elephant sections with his head, marking the feet, ears and her body, and so forth then in fact we are doing an analysis of the elephant. 
In doing teaching and learning process, especially learning a foreign language, it can be ensured if the students ever make mistakes. It cannot be avoided because making mistakes is an important part in the process of language acquisition (Corder, 1973). This error would require a gradual correction of teachers so as not to interfere with communications in the use of the language. However, errors to be corrected necessary in the selection because it can disrupt communications. As a result, learners will feel frustrated and lose motivation. As for the study of language learning, language deviations usually are divided into errors and mistake.Meanwhile, according to Corder, there are two kinds of mistakes made by learners.Among the errors and mistakes, they are difficult to distinguish without undertaking a careful analysis. But according to Baradja, a mistake at an aberration or deviation is steady, systematic and describes the competence of learners at some stage. While according to Corder, the type of error may vary according to the level of the learner. It is due to an error reflecting the pattern language learners when learning the target language. An error is not constant deviation, nor systematic and do not describe the ability of learners at some stage. The mistake is only caused by physical factors, such as fatigue and lethargy or other psychological factors, such as sadness, excitement extreme and overwhelming anger. Thus the error only relates to performance.

\subsection{Definition of Language}

According to Kridalaksana, the language is a symbol of an arbitrary of sound system used by human being to cooperate with others to communicate and identify themselves. This definition is more emphasis on the figure of the language itself. In line with the above definition, Joseph Broam as quoted by Bahtiar said that language is a structured system of arbitrary phonetic symbols used by members of a social group as a tool to get along with each other.

Some of the interesting things that can be inferred from the definitions are;

a. Language is a system

b. As a system, the language is Arbitrary, and

c. As an arbitrary system, the language can be used to interact with others and with yourself.

\subsection{Error Analysis Method}

Corder (1974) offers a five-step analysis of errors are:

a. collecting examples of errors of language learners

b. identifying errors learners

c. describes the language learner errors

d. describes error language learners, and

e. evaluate learner errors

\subsection{Classification of Linguistics Errors}

Based on its taxonomy, errors can be classified into four, namely: linguistic category error, error performance, comparative error, error effect to communication. Error in linguistic category include:

a. phonology, the error associated with the sounds of language, in Arabic it is closely associated with letter

b. morphology, the error associated with the use of procedures or forms of words

c. syntax, the error associated with the use of syntax

d. semantic, that errors related to language usage errors of meaning

e. lexicon, which annoyed Alian relating to the use of vocabulary and expressions

f. errors discourse, namely the error associated with the error utterances in a specific theme.

While error performance category includes :

a. avoid or eliminate the key points

b. adding un-important elements

c. incorrectly formulated points of linguistics.

\section{DISCUSSION}

The description of data is intended to provide a snapshot of the data study technique of content analysis that is phonological errors in speaking Arabic done by 20 students as respondents in this research at Pesantren Nurul Hakim Medan. In accordance with the level of phonological error that would be analyzed, the description of the data in the study are classified into several parts: 1) Errors in the level of phonological segmental. 2) Cause of error at the level of phonological segmental. After describing in the form of error, then data is submitted to the table to explain the error. Table created based on the number survey respondents as many as 20 people in class XI Pondok Pesantren Modren Nurul Hakim, Medan.Relating to the level of errors to be investigated, the description of the data in this study are classified into phonology emphasizing to segmental error consisting of vowels, diphthongs, consonants and consonant clusters. In this case, each discussion will be 
elaborate into a table containing of five (5) columns, namely, the first column is the number of respondents, the second column is the error number, the third column is the level of error type mpa segmental phonology and supra-segmental, fourth column form errorstaxonomic structure of birth (substitution, omission, addition or misorder)and the fifth column is the source causes of error (inter-lingual or intralingual) and making accumulative error percentage based on the error and creating tabulation. After making evaluation and knowing the error, than we will know which problem appear dominant in Arabic communication doing by students at Pesantren Modren Nurul Hakim Medan.Based on the analysis done, then the it finds phonological error committed by respondents which can be classified as follows:

Phonological error at the level of segmental

Table. 1Frequency of errors at the level of phonological segmentalbased on form of errors

\begin{tabular}{|c|c|c|c|c|}
\hline Phonem & Substitution & Addition & Omission & Total \\
\hline Vocal & 4 & 2 & 1 & 7 \\
\hline Diphthong & 0 & 0 & 0 & 0 \\
\hline Consonant & 13 & 1 & 1 & 15 \\
\hline Consonant cluster & 0 & 0 & 0 & 0 \\
\hline Total & 17 & 3 & 2 & 22 \\
\hline
\end{tabular}

Based on the table 1 above, it can be seen on segmental phonological errors which are most numerous in consonant phonemes are 15, taxonomic structure of birth at the replacement (substitution) is 13 errors, addition is 1 error and omission is 1 error, error being the vowel phonemes are 7 errors on replacement substitution is 4 errors, addition is 2 and omission is 1 error.

Table.2The percentage of errors at the level of phonological segmental

\begin{tabular}{|c|c|c|}
\hline Phoneme & Total & Percentage (\%) \\
\hline Vocal & 7 & 31,82 \\
\hline Diphthong & 0 & 0 \\
\hline Consonant & 15 & 68,18 \\
\hline Consonant cluster & 0 & 0 \\
\hline Total & 22 & $100 \%$ \\
\hline
\end{tabular}

Table.3Percentage Error phonological at the level of Segmental

\begin{tabular}{|c|c|c|c|}
\hline No & Kinds of error & Total & Percentage (\%) \\
\hline 1. & Substitution & 17 & 77.27 \\
\hline 2. & Addition & 3 & 13.64 \\
\hline 3. & Omission & 2 & 9.09 \\
\hline \multicolumn{2}{|r}{} & 22 & $100(\%)$ \\
\hline
\end{tabular}

Based on the table above, it shows that the percentage in phonological error when speaking Arabic at the level of segmental, percentage is $31.82 \%$ and consonant phonemes as many as 15 errors with the percentage of $68.48 \%$. While at the diphthong phonemes and consonant clusters, there is no errors.Based on the table above, at the level of segmental phonology, it can beseen that at the level of segmental phonological errors in taxonomy structure that is born, the most common mistake made by respondentsin speaking Arabic is a form of error substitution consisting of 17 error by as much as $77.27 \%$. Medium error is addition consisting of 3 with a percentage error

as much as $13.64 \%$ and the least mistakes is the omission 2 with the percentage error by as much as $9.09 \%$.

\section{Errors at the level of segmental}

Vocal

Respondents make a mistake due to the influence of target language(intralingual) such as:

- vowel $\mathrm{V}[\mathrm{u}]$ with *[u] at the word usrati

- vowel V [u] with * [u] in words dhllu

- vowel V [ 'a] with *[a] in the word / asy'uru

- interlingual cause. Vokal V [a] with *[a] in the word tur'atun

Respondents make a mistake due to the influence of first language (interlingual) such as: 
- vokal [u] at the end of the word */zahabu/ V/zahabu/

- Vocal [a]in the word */ajlasa / V /ajlasa'

- consonant [fa] at [p] in the word /hanifan/,

- Sound [z] at [s] in the word /hafiz '.

- sound [p] at the word faraftu/.

- sound [z] at the word [s] in a word /mauzun,

- sound $[\mathrm{z}]$ in $[\mathrm{J}]$ at the word /izan/, sound [zh] in [s] at the word /istayikazhtu/.

- sound $[\mathrm{z}]$ in $[\mathrm{s}]$ at the word /tilfizi.

- sound [qaf] in [kaf] at /qadiman'

- sound [Lam] /fas./at the word /faslun

\section{CONCLUSION}

Based on the results of data analysis in research findings, it can be described on phonological errors in Arabic speaking that Shape error on segmental level can be seen that the error phonological taxonomy structure in the form of birth, namely, the most error done by respondents in spoken Arabic is the form error replacement (substitution) accounted for 17 errors with percentage as much as $77.27 \%$, the error being the addition totaling 3 percentage error by as much as $13.64 \%$ and fewest errors is omission (omission) amounted to 2 fault with the percentage as much as $9.09 \%$.

\section{REFERENCES}

[1] Abu Hilal Al-Askary, Al-Furuq Al-Lughawiyah (Bairut : Dar Al- Kutub Al-Ilmiyah, 1992Al ajah,Abdul Fatah Hasan, Asalib Tadris Maharatul Lugah Arabiyah wa Adabuha Oman/ Ardan: Darul Kitab al Jamil2001

[2] Al-Suyuthy, Abdurrahman Jalaluddin, tt, al-Muzhir fi Ulum al- Lughah wa Anwa'iha, Dar al-Fikr, Beirut Libanon, vol I

[3] Badri, Kamal Ibrahim, Ilmu Lugah Al-Mubaramaj Saudi Arabiyah, Imadat Syabauni Al-Maktab Jama'tu Malik Su'u d - Riyad, 1982

[4] James, Errors in Language Learning and USE AddidisionWesley: Longman Limited , 1998James, Error in Language Learning an Use : Exploring Error analysis London ; Longman, 1998

[5] Chaer, Abdul, Fonologi bahasa Indonesia Jakarta: Reneka Cipta, 2009Coorder, S.P. The Significe of Leamer's Errors Oxford: Oxford University Press, 1981

[6] Corder, Errors Analysis, dalam J.P Allem\& Pit S. Corder (eds) The Adenburg Course in Oplied Linguistiky Vol. 5 (London: OVP, 1974

[7] D. Shalahuddin, Shalih Hasanin, Dirasatu i'lmi Lugah, Darul Ulum ; Taba'atu wal Nasyar 1984 H-

[8] $1405 \mathrm{M}$

[9] Harmer, Jeremy, The Practice ofEnglish Teaching England: Person Education Limited, 2001Hijazi, Mahmud Fahmi. Ilmu al-Lugah al-Arabiyah Kuwait: Wakalah al-Matbu'ah, 1973

[10] Holsti, Ole R, Content Analysis for the Social Science and Humanities, Reading, Massachusetts : Addison - Westley Publishing, 1969

[11] Iskandar Ifan, Perbandingan Fonem-Fonem Bacaan Bahasa Inggris, Indonesia dan Arab dan Implikasi dalam Pengajaran FonemFonem Bahasa Inggris, Jakarta: Universitas Negeri

[12] Jakarta, 1997

[13] Jack C. Richard, Jhon Piatt \& Hedi Piatt Longman, Dictionary o f Language Teaching and Apllied

[14] Linguistics, Malaysia: Longman Group Limited, 1997

[15] Jack Richard, Error Analysis Perspectives o n secon d Language London: Longman Grup Limited,

[16] 1978

[17] Juliansyah, Noor, Metode Penelitian Jakarta: Kencana, 2011

[18] Kamal, Ibrahim Badri Ilmu al-Lugoh al- Mubarmaj, (Riyad: Jami'ah al-Malik Su'ud, 1982

[19] Kushartanti, dkk, Pesona bahasa, langkah awal memahami linguistic Jakarta: Gramedia Pustaka

Utama, 2012idar, G. Arsjad dan Mukti, Pembinaa Kemampuan berbahasa Indonesia Jakarta: Erlangga, 1991Mansoer Pateda, Sosiolonguistik, Penerbit: Angkasa Bandung, 1999

[20] Moleong, Lexy J, Metodologi Penelitian Kualitatif Edisi Revisi, Bandung: Rosdakarya,2011Nasr Raja T, Ed,D, The structure o f Arabic, from Sound to Sentence Beirut; Librairie Du Liban, 1967

[21] Nazir, Moh. Metode Penelitian (Jakarta: Ghalia Indonesia, 1988Penny, Ur. A Course in Language Teaching: Practice and Theory, Cambridge: Cambridge Universitu Press. 2001.

[22] Rakhmat, Jalaluddin, Metode Penelitian Komunikasi. Bandung: PT Remaja Rosdakarya, 1991Redaksi, Belajar Bahasa Arab, www.eramuslim.com, diakses pada tanggal 10 Maret 2015.Richard, Jack. C, Jhon Platt \& Haidi Platt, Logman Dictionary of Language Teaching and Apllied Linguistics Malaysia:Logman Group Limited, 1997

[23] Robert Lado, Linguistics Across Cultures Applied Linguistics for Language Teachers, Michigan: The University of MichiganPress, 1957

[24] Robert Lado, Linguistik di Berbagai Budaya, terjemahan Soedjono Daijowijoyo, Ganeco. Bandung 1979Spradley, James P., Participant Observation New- York: Holt, Rinehart and Wiston, 1980

Sudjana, Metoda Statistika, Bandung: Tarsito,. 1982Yonohudiono dan Leo Idra Ardiana. AnalisisKesalahan Berbicara Jakarta: Universitas Terbuka, 2001

[25] Yusuf, Suhendra, Fonetik dan fonologi Jakarta: Gramedia Pustaka Utama, 1998Wikipedia 